\title{
Servitization Strategy of Core Manufactures in Transformation and Value Chain Governance from the Perspective of Integration Capability
}

\author{
Zhong liu \\ Management school of FuDan University, Shanghai, China \\ Shephard01@163.com \\ *Zhong liu
}

Keywords: integration capability; core manufacturer; servitization strategy; value chain governance; industrial internet platform.

\begin{abstract}
This paper identified the conceptual model of the two capabilities of system seller and system integration within industrial Internet platform of leading enterprises to develop service transformation strategy. We suggest that servitization capabilities formation of core manufactures requires its vertical integration capability of value chain for system seller, which usually tend to implementation alternative servitization strategy with capture governance in value chain governance. While servitization capabilities development of core manufacturers depends on its coordination of the external value chain network resources for system integrator, which is likely to choose adapted servitization strategy with module governance in value chain.
\end{abstract}

\section{Introduction}

System Integration is the core competence of modern high-tech manufacturing companies. Wise and Baumgartner [1] pointed out that Nokia moves downstream of the value chain by providing integrated packages of products and services, such vertical integration is often seen as a way for enterprises to reconfigure the required resources and capabilities. Similarly, Louis Gerstner, IBM CEO, who implemented a vertical integration strategy in 1993, transformed IBM into a separate set of component suppliers focusing on providing complete integrated solutions for customers' computing and service needs [2]. However, the question is: What impact will the service transformation of manufacturing core enterprises have on their value chain governance under vertical integration? At the same time, considering the rise of Internet of Things technology, upstream manufacturers re-control communication channels with end customers through smart interconnection products, and the role of downstream distributors and intermediaries is gradually weakened. How should the core enterprises in different manufacturing industries use the system integration to develop internal and external capabilities, and what kind of service transformation strategy does the manufactures support? In view of the above problems, this paper attempts to reveal the influence mechanism of industrial Internet platform on the servitization strategy transformation of manufacturing core enterprise from a perspective of system integration capability, analyzes the strategic choice and value chain governance of core enterprises in different manufacturing industries during the service transformation period. We also provide policy recommendations for the strategic decision-making of servitization transformation of manufacturing enterprises in China.

\section{Servitization literature review on system integration capability}

From resource-based perspective, System Integration Capability is a presentation of the dynamic allocation of enterprise resources. The System Integration Capability is critical to the company's broader product competition strategy and the specific position of the company's value stream in different periods of the industry. Michael Hobday [3] argue that the System Integration Capabilities of manufacturing companies have two strategic implications. First, system integrators need to be able to envision and develop the dynamic capabilities required for new product architectures and new product families, and understand how to integrate product components, skills, knowledge, and 
activities of other new products developed by other organizations to produce more complex products and services, the second is at the value chain level, where system integrators provide products and systems through market competition and vertical integration to deploy purposeful strategies to create production networks, then enable system integrators to gain the benefits of outsourcing or vertical integration at different stages of the product lifecycle.

As a complex product system, traditional System Integration emphasize dynamic technology integration capabilities and their corresponding value chain positioning issues. At this stage, with the rise of digital technology applications, manufacturing service is no longer limited to the past systems sellers of industrial, and its services are not only for corporate customers, rather, the manufacturing company reconfigures the resource capabilities of the complex system across the entire value chain, how to provide a personalized product service package for different customers and how to use the supply chain network to coordinate the production and R\&D capabilities of external suppliers becomes crucial. In reality, capital goods system integrators, represented by large-scale mechanical automation equipment, began to move downstream to provide service-intensive product systems to expand revenue and improve profitability. In contrast, Manufacturers represented by high-volume components and consumer products such as mobile phones and home appliances are gradually adopting system integration functions to improve production collaboration with upstream suppliers. In this way, the customization service of downstream consumers is realized.

\section{Theoretical framework}

\subsection{Core manufacturers' system integration capability and value chain governance}

Over the past two decades, the trend of industry modularization and open standards has increased the possibility of manufacturers focusing on component supply and system integration [4]. The success of the new service's development and deployment which is also related to the degree of control in the service value chain [5]. Under the vertical integration of the value chain, many core manufacturers have established service competitive advantages at different stages. Davies[6]used the concept of "system integration" and "system selling" initially reveals the source of organizational service ability, Davies[4] proposed two types of pure system integrator that to develop products and services solutions: (1)) the vertically-integrated systems seller that produces all the products and services components in a system (abbreviated as system seller); (2) the system integrator that coordinates the integration of components supplied by the external enterprise. Strictly, is no pure "system selling" and "system integration".

Value chain governance is an institutional arrangement of power structure [7]. The complexity of trading, the codability of knowledge, and the ability of suppliers are important variables that influence the governance model of global value chains [8]. As a pure system seller, core manufacturer has completely controlled the manufacturing of all components in the system, is responsible for the entire system design, interface and component specifications, component integration and other services. It also has proprietary interfaces and standard components, which reduces the cost of interorganizational collaboration. Therefore, its servitization capability mainly comes from the internal $R \& D$ and production side. The core manufacturers extend to the upstream of the value chain, and based on vertical integration, the core manufacturers provide complete products and service systems and maintenance services to customers for the whole product life cycle Under these conditions, the role of distributors and intermediaries downstream of the value chain will be marginalized, and suppliers' dependence on core manufacturers will deepen. From the aspect of pure system integrator, the core manufacturers is responsible for the design and integration of externally provided products and service components into customer-specific solutions. Its servitization capabilities mainly derived from the specialization and modularization advantages of product component supply, the convenience of interface standardization, and the selection and integration of different supplier technologies and products. The integration capabilities approach emphasizes the management capabilities of external network partners that centered on the development of solutions, this allows enterprises to focus on existing core competencies and develop service components using the high-quality resources 
provided by external. Therefore, core manufacturer can respond quickly and accurately to market changes. The cooperative relationship between manufacturers and external networks are important determinants of supply chain performance and value creation. Value chain governance comparison of system integrator and system seller are shown in Table 1.

Table 1 Value chain governance comparison of pure system integration

\begin{tabular}{cccccc}
\hline & $\begin{array}{c}\text { Transaction } \\
\text { Complexity }\end{array}$ & $\begin{array}{c}\text { Knowledge } \\
\text { Codability }\end{array}$ & $\begin{array}{c}\text { Suppliers } \\
\text { Capacity }\end{array}$ & $\begin{array}{c}\text { Power } \\
\text { Asymmetry }\end{array}$ & $\begin{array}{c}\text { Value chain } \\
\text { Governance } \\
\text { Model }\end{array}$ \\
\hline $\begin{array}{c}\text { Pure system } \\
\text { seller }\end{array}$ & High & High & Low & High & Capture \\
\hline $\begin{array}{c}\text { Pure system } \\
\text { integrator }\end{array}$ & High & High & High & Low & Modular \\
\hline
\end{tabular}

\subsection{Industrial Internet Platform Enterprise and Servitization transformation strategy}

Industrial Internet platform is an industrial cloud integration system based on data collection, aggregation and analysis, the industrial scene application in the integrated system integrates resources within various value chain links such as $R \& D$, manufacturing, warehousing logistics, and operation and sales. At present, the IT layer of Industrial Internet platforms, which refers to the end-to-end business processes, including ERP and CRM systems, supply chain management, logistics, human resources and financial systems, are widely used in the field of manufacture industry. The OT layer of Industrial Internet platform is mainly for the monitoring and control of industrial equipment in the operation of the plant. The hardware including machines, controllers, sensors and actuator, software including PLC (Programmable Logic Controller), DCS (Distributed Control System), FCS (Fieldbus Control System) and other equipment systems. From a system integration perspective, the industrial internet platform enterprise combines two elements of vertical system sellers and external component system integration to provide the product service solutions.

The product life cycle within value chain involves three types of service strategies: smooth service in product sales, adapted service in production process and alternative service in product use. Three types of servitization transformation strategies is shown in Table 2:

Table 2 Classification of servitization transformation strategy for manufacturer

\begin{tabular}{lll}
\hline \multicolumn{1}{c}{ Smooth service } & \multicolumn{1}{c}{ Adapted service } & \multicolumn{1}{c}{ Alternative service } \\
\hline $\begin{array}{l}\text { Promote product sales without } \\
\text { significantly changing the } \\
\text { functionality of the product }\end{array}$ & $\begin{array}{l}\text { Meet customer's needs immediately, help } \\
\text { manufacturers develop new function or } \\
\text { increase product adaptability. }\end{array}$ & $\begin{array}{l}\text { Service purchase or lease } \\
\text { replaces the purchase of the } \\
\text { product, and the ownership of } \\
\text { the product remains during the } \\
\text { transaction. }\end{array}$ \\
\hline $\begin{array}{l}\text { Low interaction of customer } \\
\text { manufacture, service is an } \\
\text { accessory to product, low } \\
\text { complementarity between } \\
\text { service and product, value } \\
\text { capture from product. }\end{array}$ & $\begin{array}{l}\text { High interaction of Customer-manufacturer, } \\
\text { service is embedded in products, service is the } \\
\text { complementarity of product functions. value } \\
\text { capture from the integration package of } \\
\text { product-service combination. }\end{array}$ & $\begin{array}{l}\text { High interaction of Customer- } \\
\text { manufacturer, service output is } \\
\text { replacement of production } \\
\text { function. Alternative Service } \\
\text { embedded in application } \\
\text { scenarios, value capture from } \\
\text { product operation performance. }\end{array}$ \\
\hline $\begin{array}{l}\text { Example: Training, after-sale } \\
\text { repairing and so on. }\end{array}$ & $\begin{array}{l}\text { Example: Home appliances' customization, } \\
\text { remote maintenance, personalized } \\
\text { customization of automobile and so on. }\end{array}$ & $\begin{array}{l}\text { Example: Bike-sharing, cloud } \\
\text { print, flat rate of the Rolls- } \\
\text { Royce engine and so on. }\end{array}$ \\
\hline
\end{tabular}

So there are two ways for the manufacturer to extend to the upstream and downstream of the value chain though the system integration capability of the industrial Internet platform: One is to embed services into product sales and usage scenarios outside the enterprise through system sales, the other is to embed services into the whole process of product design, production, $R \& D$, manufacturing and sales through system integration. Based on the connection of internal and external value steam, this research extends the whole life cycle of the product upward to the R\&D stage and downward to whole service life of the product after sale. On the point of standard basis for classification of servitization 
strategies in the manufacturer [9]. The product life cycle of this research involves three types of services: Smooth service in product sales, enhanced service in production process and alternative service in product use.

\section{Research conclusion and suggestions}

System integration capability is the core competence of modern manufacturing companies, especially technology-based manufacturing companies. Integrated solution development for products and services is the result of developing system integration capability. In order to realize the transformation and upgrading of China's manufacturing servitization, we believe that manufacturing in other industries should further explore their own development path suitable for the system integration in the future. On the one hand, the manufactures may improve traditional manufacturing capabilities by introducing ICT information construction such as IoT sensing and industrial cloud, on the other hand, the manufactures may support the servitization strategy by sharing the business model innovations such as leasing and supply chain finance. Finally, manufacturing companies should strengthen cooperation with knowledge-intensive service companies such as SAP, Amazon, and Alibaba, promote the upgrading of enterprise service capabilities, and explore new market opportunities.

\section{References}

[1] Wise, R. and P. Baumgartner., 'Go downstream: the new profit imperative in manufacturing' [J]. Harvard Business Review ,1999, 28 (5): 133-141.

[2] L.V. Gerstner. Who said elephants can't dance? Inside IBM's historic turnaround [M]. Harper Collins Publishers, London, 2002:130-132.

[3] Michael Hobday, Andrew Davies, Andrea Prencipe. Systems integration: a core capability of the modern corporation[J]. Industrial and Corporate Change, 2005,14(6): 1109-1143

[4] Andrew Davies, Tim Brady, Michael Hobday. Organizing for solutions: Systems seller vs. systems integrator[J]. Industrial Marketing Management, 2007, 36(2): 183-193.

[5] Raynor, M. E., \& Christensen, C. M. Integrate to innovate: The determinants of success in developing and deploying new services in the communications industry[M]. New York: Deloitte Research, 2002:10-11.

[6] Davies, A. Moving base into high-value integrated solutions: a value stream approach[J]. Industrial and Corporate Change, 2004, 13(5):727-756

[7] Gary Gereffi, John Humphrey, Timothy Sturgeon. The governance of global value chains[J]. Review of International Political Economy, 2005, 12(1):78-104

[8] Gary Gereffi. International Trade and Industrial Upgrading in the Apparel Commodity Chain[J]. Journal of International Economics, 1999,48(1): 37-70.

[9] Marco Paiola, Nicola Saccani, Marco Perona, Heiko Gebauer. Moving from products to solutions: Strategic approaches for developing capabilities[J]. European Management Journal, 2013, 31(4):390-409. 